\title{
Polymorphism Study of POU1F1 Gene in Mandya and NARI- Suwarna Sheep
}

\author{
H.R. Abhilash ${ }^{1}$, S. Naveen Kumar ${ }^{1}$, R. Nagaraja ${ }^{2}$, H.M. Yathish ${ }^{1}$, V. Jagadeeswary ${ }^{3}$
}

10.18805/IJAR.B-4777

\begin{abstract}
Background: The mutations in POU1F1 gene result in deficiency of GH, PRL and TSH- $\beta$ expression and thus have an indirect effect on development and reproduction. The present study was conducted to determine and compare the polymorphism of POU1F1 gene in Mandya and NARI-Suwarna Sheep.

Methods: Blood samples were collected from 50 each of Mandya and NARI-Suwarna sheep and genomic DNA was isolated following Miller's high salt method. PCR-RFLP analysis was performed for exon 3 and exon 4 regions of POU1F1 gene, whereas, PCR-SSCP analysis was performed for exon 6 region of POU1F1 gene.

Result: The PCR products of sizes $365 \mathrm{bp}, 508 \mathrm{bp}$ and $501 \mathrm{bp}$ for exon 3, exon 4 and exon 6 regions of POU1F1 gene, respectively were successfully amplified. PCR-RFLP analysis of exon 3 and exon 4 regions of POU1F1 gene with Alul and EcoRI restriction enzymes, respectively revealed monomorphism in both Mandya and NARI-Suwarna sheep. The PCR-SSCP analysis of exon 6 region of POU1F1 gene revealed two patterns, P1 and P2 with frequencies of 98 and 2 per cent, respectively in Mandya sheep and 90 and 10 per cent, respectively in NARI-Suwarna sheep. The alignment of P1 and P2 pattern sequences revealed two SNPs (109 G>C and $112 \mathrm{~T}>\mathrm{A}$ ) in Mandya sheep, whereas 3 SNPs (218 T>G, $225 \mathrm{G}>\mathrm{A}$ and $264 \mathrm{~T}>\mathrm{A}$ ) were revealed in NARI-Suwarna sheep. Polymorphism was successfully established at exon 6 region of POU1F1 gene.
\end{abstract}

Key words: Genetic polymorphisms, Mandya sheep, NARI-Suwarna sheep, POU1F1.

\section{INTRODUCTION}

Mandya sheep is considered as a best meat breed with respect to its conformation (Acharya, 1982). Its meat is regarded as the most nutritious and high quality mutton in human diets at national and international spectrum of sheep products (Dinakar et al., 2019). These animals are predominantly distributed in Mandya and adjacent districts of Karnataka. NARI-Suwarna sheep with more than 60 per cent ewes having twin was developed by Nimbkar Agriculture Research Institute (NARI), Phalton, through introgression of $F e c B$ gene from the prolific Garole breed of Sunderban, West Bengal into non-prolific locally adapted Deccani breed of Maharashtra (Nimbkar et al., 2002).

Identification of genetic markers in relation to growth rate and its possible use in Marker Assisted Selection (MAS) will speed up the genetic progress. In general, the crucial step to ascertain a MAS system is to fishing out and validating the genetic markers of growth traits (Allan et al., 2007). For growth traits, growth hormone $(G H)$, growth hormone receptor $(G H R)$, Insulin like growth factor 1 (IGF1), leptin, pituitary specific transcription factor - 1 (POU1F1), myostatin (MSTN) and bone morphogenetic protein (BMP) genes are necessary for bone formation, birth weight, weaning weight, body condition and muscle growth (Supakorn, 2009).

The POU1F1 belongs to the large family of POU domain proteins. The POU1F1 (also known as PIT-1 or GHF-1) is a tissue-specific transcription factor which is mainly expressed in the anterior pituitary. This protein has a certain role in the
1Department of Animal Genetics and Breeding, Veterinary College, Hebbal-560 024, Bengaluru, Karnataka, India.

${ }^{2}$ Veterinary College, Gadag-582 102, Karnataka, India.

${ }^{3}$ Veterinary College, Hassan-573 202, Karnataka, India.

Corresponding Author: S. Naveen Kumar, Department of Animal Genetics and Breeding, Veterinary College, Hebbal-560 024, Bengaluru, Karnataka, India. Email: navingen@gmail.com

How to cite this article: Abhilash, H.R., Naveen Kumar, S. Nagaraja, R., Yathish, H.M. and Jagadeeswary, V. (2022). Polymorphism Study of POU1F1 Gene in Mandya and NARISuwarna Sheep. Indian Journal of Animal Research. DOI: 10.18805/ IJAR.B-4777.

Submitted: 16-09-2021 Accepted: 18-12-2021 Online: 18-01-2022

transcriptional adjustment of growth hormone $(\mathrm{GH})$ and prolactin $(P R L)$ genes. Additionally, POU1F1 is also involved in the activation of thyroid-stimulating hormone, POU1F1 itself and growth hormone-releasing hormone receptor (GHRH-R) genes. Moreover, besides its role in gene activation, POU1F1 is essential for differentiation, reproduction and survival of somatotrope and lactotrope as well as thyrotrope cells. The ovine POU1F1 gene contains five introns and six exons and is located on chromosome 1 (Bastos et al., 2006).

Ozmen et al. (2014) studied the association of SNP in exon 6 region of POU1F1 gene with milk productive traits in Turkish sheep breeds (Sakiz, White Karaman and Awassi). They reported a significant association of milk yield, fat and 
lactose with TT and CC genotypes in Sakiz sheep. JalilSarghale et al. (2014) investigated the SNPs at exon 3 region of POU1F1 gene and its association with growth and biometric traits in two Iranian sheep breeds (Zel and LoriBakhtiari). They found that AA genotype had a higher weaning weight than those with GG genotype and opined that POU1F1 polymorphism can be used as molecular marker for production traits.

The present study was conducted to find out and compare the polymorphism of POU1F1 gene in Mandya and NARI-Suwarna sheep, if any.

\section{MATERIALS AND METHODS}

Blood samples were collected from 50 Mandya sheep from farmers' flock distributed over villages of Malavally taluk, Mandya district, Karnataka and 50 NARI-Suwarna sheep from the flock maintained at Department of Veterinary Gynaecology and Obstetrics, Veterinary College, KVAFSU, Hebbal, Bengaluru. Genomic DNA was isolated from venous blood by following high salt method as described by Miller et al. (1988) with a few modifications.

The primers previously published by Ekegbu et al. (2018) and Al-Khuzai and Al-Anbari, (2018) were utilized for amplification of exon 3 and 4 regions of POU1F1 gene, respectively. Whereas, for amplification of exon 6 region of POU1F1 gene, the primer was designed using PRIMER 3 PLUS software by referring the Ovis aries sequences available in NCBI website. The details of the primers used for amplification of POU1F1 gene are presented in Table 1.

The amplification of exon 3,4 and 6 regions of POU1F1 gene were performed in a total volume of $25 \mu \mathrm{l}$ which consisted of $12.5 \mu \mathrm{l}$ of Red PCR master mix, $1 \mu \mathrm{l}$ $(10 \mathrm{pmol} / \mu \mathrm{l})$ each of forward and reverse primer, $9.5 \mu \mathrm{l}$ of PCR grade water and $1 \mu$ of template DNA. The PCR reaction was carried out with an initial denaturation temperature of $95^{\circ} \mathrm{C}(4 \mathrm{~min}), 35$ cycles of $94^{\circ} \mathrm{C}(45 \mathrm{sec})$, $55.8^{\circ} \mathrm{C}(45 \mathrm{sec})$ and $72^{\circ} \mathrm{C}(60 \mathrm{sec})$ for exon 3 and 4 regions and 34 cycles of $94^{\circ} \mathrm{C}(60 \mathrm{sec}), 60^{\circ} \mathrm{C}(60 \mathrm{sec})$ and $72^{\circ} \mathrm{C}(60 \mathrm{sec})$ for exon 6 region of POU1F1 gene followed by final extension at $72^{\circ} \mathrm{C}(10 \mathrm{~min})$. The PCR amplified products were resolved on 1.5 per cent agarose in parallel with $100 \mathrm{bp}$ DNA ladder and photographed under gel documentation system (Bio rad Molecular imager Gel Doc XR+, USA).

The PCR products of the exon 3 and 4 regions of POU1F1 gene were digested with $A / u l$ and EcoRI restriction enzymes, respectively. The digestion was done in a total volume of $30 \mu \mathrm{l}$ which consisted of $2 \mu$ l of $10 \mathrm{X}$ buffer, $10 \mu \mathrm{l}$ of PCR amplicon, $1 \mu \mathrm{l}$ of RE and $17 \mu \mathrm{l}$ of Nuclease free water (NFW) with incubation at $65^{\circ} \mathrm{C}$ for 3 hours. The RE digested products were resolved on two per cent agarose gel agarose in parallel with 100 bp DNA ladder and photographed under gel documentation system (Bio rad Molecular imager Gel Doc XR+,USA). Based on visualization of different band patterns, genotypes were determined.

The PCR product of exon 6 region of POU1F1 gene was subjected to single-strand conformation polymorphism (SSCP) by using 12 per cent polyacrylamide gel. The 12 per cent polyacrylamide gel comprised of $15 \mathrm{ml}$ of Acrylamide:Bisacrylamide (29:1), $5 \mathrm{ml}$ of 10x TBE, $32.6 \mathrm{ml}$ of autoclaved triple distilled water, $330 \mu$ of 10 per cent ammonium per sulphate and $70 \mu$ of TEMED. Approximately $12 \mu \mathrm{l}$ of PCR product was mixed with $8 \mu \mathrm{l}$ of formamide dye and properly mixed. The mixture was denatured at $95^{\circ} \mathrm{C}$ for 10 minutes and snap cooled on ice for 3 minutes. The product was carefully loaded into the gel. The electrophoresis was performed for 5 hours at 150 volts at $16^{\circ} \mathrm{C}$. The gel was stained with silver staining after the run in order to visualize the banding pattern.

The PCR products showing different patterns in RFLP and SSCP were custom sequenced by double pass sequencing method using primers used for amplification of different products.

\section{RESULTS AND DISCUSSION}

About 200 - $300 \mu \mathrm{g}$ of good quality DNA per $10 \mathrm{ml}$ of venous blood was obtained in the present study by following Miller's high salt method.

The PCR products of sizes 365, 508 and 501 bp (Fig 1, 2 and 3 ) were successfully amplified for exon 3 , exon 4 and exon 6 region of POU1F1 gene, respectively in the studied population.

The restriction enzyme (RE) digested products of exon 3 region of POU1F1 gene resolved on agarose gel electrophoresis revealed fragments of sizes of 112, 105 and $95 \mathrm{bp}$ in one band and 31 and $22 \mathrm{bp}$ fragments in another band. The RE have cut the PCR amplicons to give the above mentioned fragments indicating AAgenotype in both Mandya and NARI-Suwarna Sheep (Fig 4). Contrast to the present study, Bastos et al. (2006) observed polymorphism in 'Churra da Terra Quente' sheep. Sumantri et al. (2009) reported polymorphism in local sheep from Jonggol Animal Science

Table 1: Details of primers used for amplification of Ovine POU1F1 gene.

\begin{tabular}{llcc}
\hline Region & Primer sequence & Expected product size (bp) & References \\
\hline Exon 3 & F: 5'ACTGGCCTTCACAGAACAATC3' & 365 & Ekegbu et al., 2018 \\
& R: 5'GACTTTGCAGATGGGGTTGT3' & & Al-Khuzai and Al-Anbari, 2018 \\
Exon 4 & F: 5'ATACCAGGCAATTCTACACTG3' & 508 & - \\
& R: 5'GGCCTTGCTTTTCTTTATAG3' & & 501 \\
Exon 6 & F: 5'CAATAACCTGAGTTCTGGGGGA3' & & \\
& R: 5'TCAGGCTTGTTTTCACCCGT3' & & \\
\hline
\end{tabular}


Teaching and Research Unit (JASTRU) farm in Bogor using PCR-RFLP with Hinf1 restriction enzyme. By employing PCR-RFLP with Acil restriction enzyme, polymorphism was reported in Iranian sheep breeds (Zel and Lori-Bakhtiari) by Jalil-Sarghale et al. (2014). But, by following PCR-SSCP analysis many authors viz., Ekegbu et al. (2018) in New Zealand sheep breeds (NZ Romeny and Merino), Bahrami et al. (2014) in Mehraban sheep, Sadeghi et al. (2014) in Iranian sheep breeds (Zel and Lori-Bakhtiari) and Negahdary et al. (2013) in Makooei sheep reported polymorphism in exon 3 region of POU1F1 gene.

The restriction enzyme digested products of exon 4 region of POU1F1 gene resolved on agarose gel electrophoresis revealed fragments of sizes 275 and 233 bp. The RE have cut the PCR amplicons to give rise to two bands indicating AA genotype in both Mandya and NARISuwarna Sheep (Fig 5). This is in agreement with the reports of Sudhakar (2009) in Nilagiri and Mecheri sheep breeds and Bastos et al. (2006) in 'Churra da Terra Quente' sheep, who also reported absence of polymorphism in exon 4 region of POU1F1 gene. Contrast to the present study, AL-Khuzai and Al-Anbari, (2018) reported polymorphism in Iraqi Awassi sheep by following PCR-RFLP. They reported two genotypes, $\mathrm{MM}$ and $\mathrm{NN}$ with frequency of 0.58 and 0.42 , respectively and two alleles with frequency of 0.58 and 0.42 , respectively. Similarly, Ansari et al. (2008) reported three genotypes (AA, $A B$ and $B B$ ) in Baluchi Sheep.

In the present study, PCR-SSCP technique was employed to determine the polymorphism at exon 6 region of POU1F1 gene. The PCR-SSCP analysis revealed two patterns, P1 and P2 both in Mandya and NARI-Suwarna sheep (Fig 6). The frequency of P1 and P2 in Mandya was 98 and 2 per cent, respectively whereas, in NARI-Suwarna it was 90 and 10 per cent, respectively. The proportion of

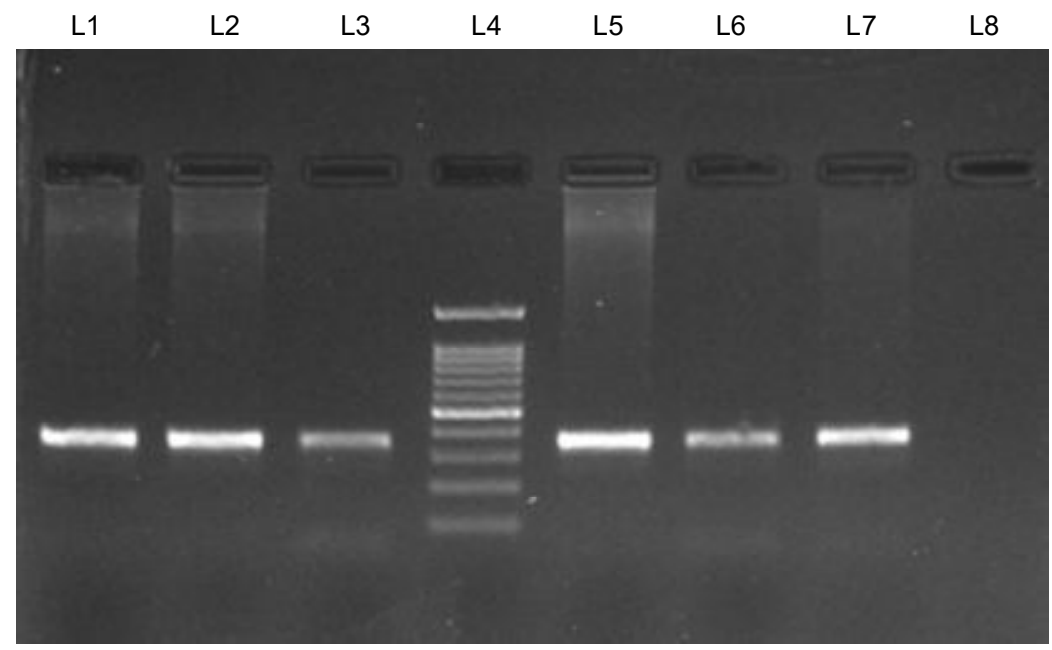

Fig 1: Agarose electrophoresis gel showing PCR amplicons of exon 3 (365 bp) region of POU1F1 gene. Lanes 1-3: PCR Amplicons of Mandya.

Lane 4: 100 bp DNA ladder.

Lanes 5-7: PCR Amplicons of NARI-Suwarna.

Lane 8: No template control (NTC).

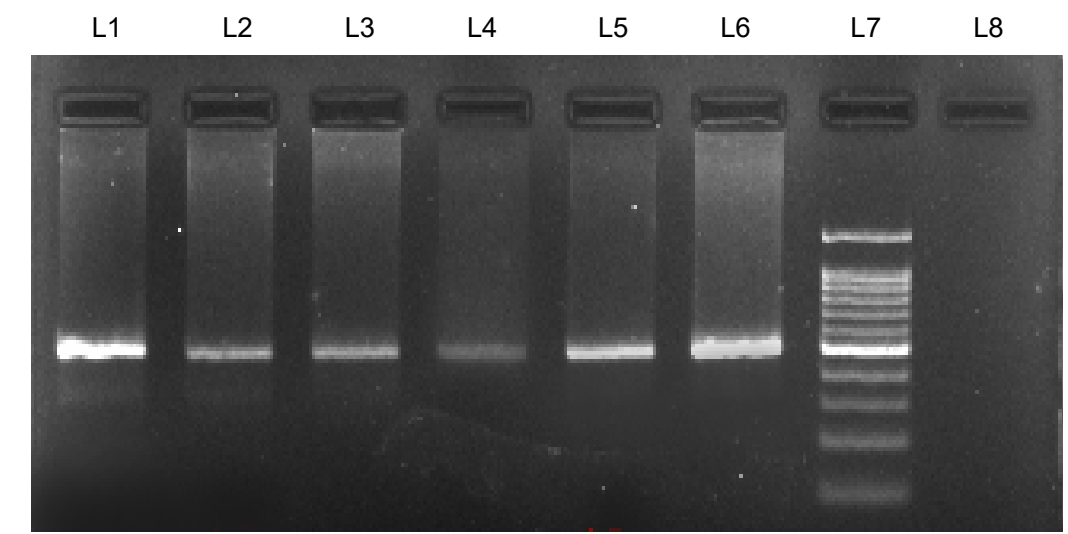

Fig 2: Agarose electrophoresis gel showing PCR amplicons of exon 4 (508 bp) region of POU1F1 gene. Lanes 1-3: PCR Amplicons of Mandya.

Lanes 4-6: PCR Amplicons of NARI-Suwarna.

Lane -7: 100 bp DNA ladder.

Lane 8: No template control (NTC). 
animals with P1 was more in both Mandya and NARISuwarna population. In agreement to the current study, Ozmen et al. (2014) reported two genotypes (TT and CC) in Sakiz sheep by PCR-RFLP technique with Alul restriction enzyme. Similarly, Bai et al. (2016) conducted PCR-RFLP analysis and reported polymorphism in five sheep breeds (large-tailed Han, small-tailed Han, Yuxi fat-tailed, Lanzhou large-tailed and Mongolian sheep) of China. In contrast to the present study, Bastos et al. (2006) reported no polymorphism at exon 6 region of POU1F1 gene in 'Churra da Terra Quente' sheep.
The alignment of $\mathrm{P} 1$ and $\mathrm{P} 2$ pattern sequences of Mandya sheep revealed two SNPs, G to $C$ transversion at $109 \mathrm{bp}$ position and $\mathrm{T}$ to $\mathrm{A}$ transversion at $112 \mathrm{bp}$ position (Fig 7). Whereas, alignment of $\mathrm{P} 1$ and $\mathrm{P} 2$ pattern sequences of NARI-Suwarna sheep revealed 3 SNPS, T to $G$ transversion at $218 \mathrm{bp}, \mathrm{G}$ to A transition at $225 \mathrm{bp}$ and $\mathrm{T}$ to A transversion at 264 bp positions (Fig 8). In concurrence to the present study, Bai et al. (2016) conducted PCR-RFLP analysis and detected three SNPS at exon 6 region of POU1F1 gene in five sheep breeds (large-tailed Han, smalltailed Han, Yuxi fat-tailed, Lanzhou large-tailed and

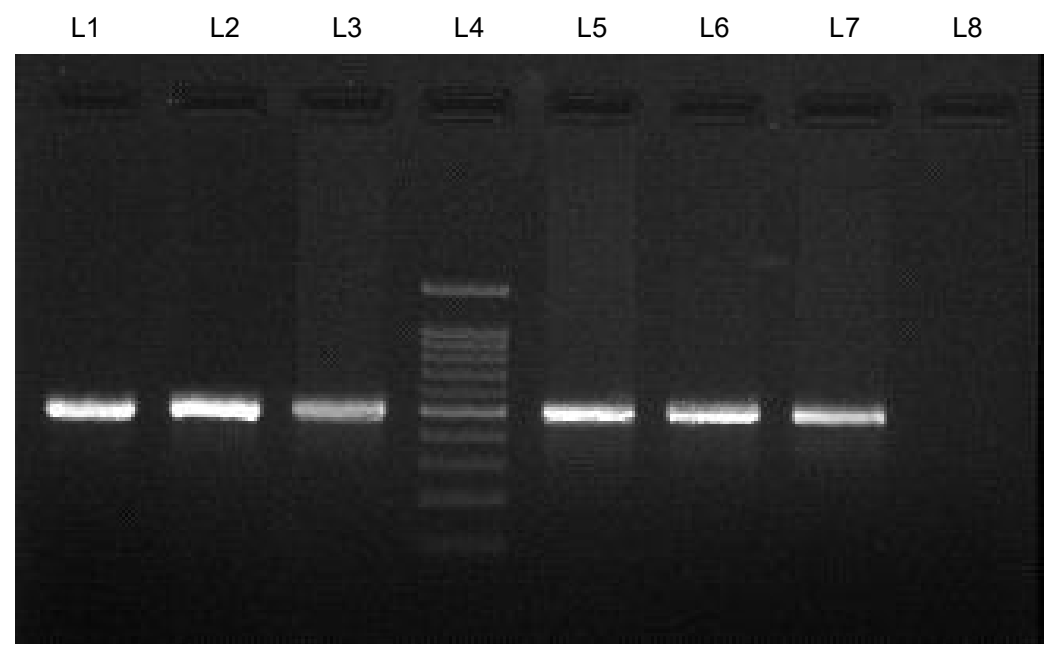

Fig 3: Agarose electrophoresis gel showing PCR amplicons of exon 6 (501 bp) region of POU1F1 gene.

Lanes 1-3: PCR Amplicons of Mandya.

Lane 4: 100 bp DNA ladder.

Lanes 5-7: PCR Amplicons of NARI-Suwarna.

Lane 8: No Template Control (NTC).

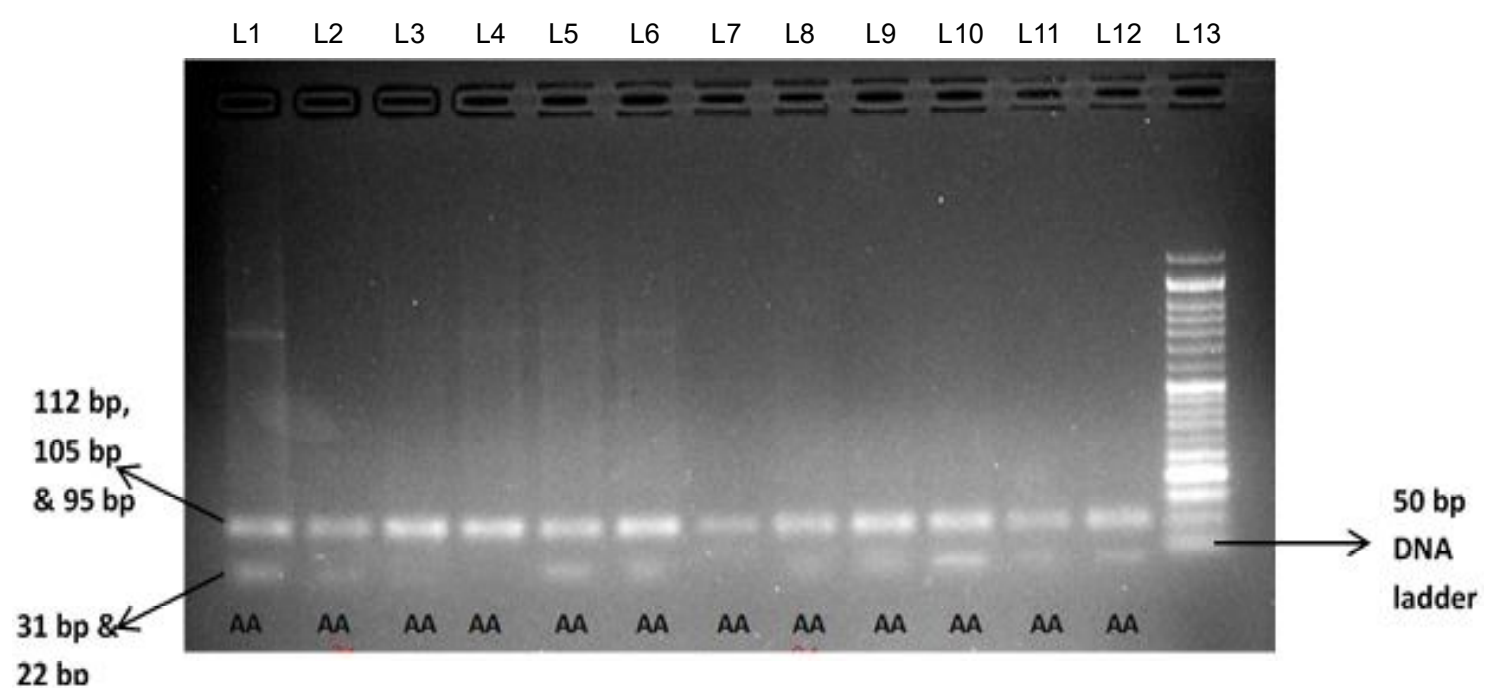

Fig 4: Agarose electrophoresis gel showing Alul restriction enzyme digested PCR - RFLP pattern of exon 3 region of POU1F1 gene.

Lanes 1-6: RFLP pattern for Mandya.

Lanes 7-12: RFLP pattern for NARI-Suwarna.

Lane 13: 50 bp DNA ladder. 


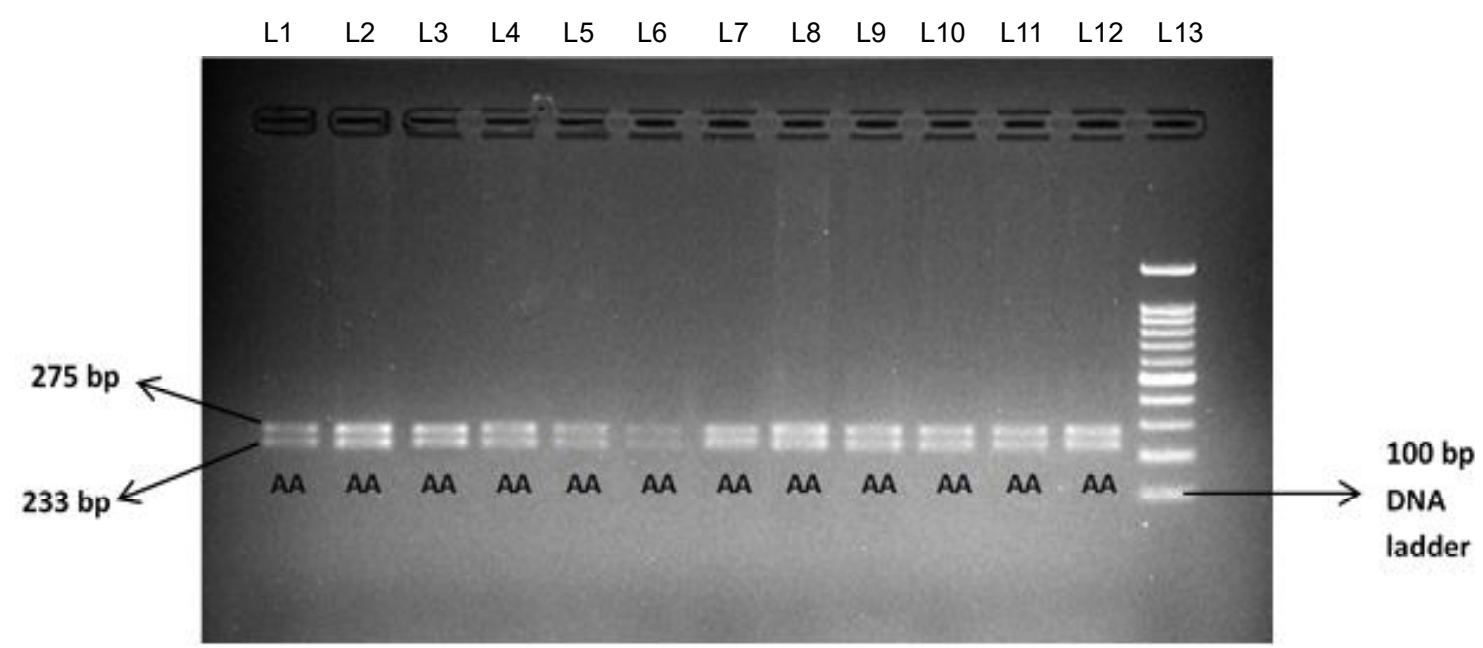

Fig 5: Agarose electrophoresis gel showing EcoRI restriction enzyme digested PCR - RFLP pattern of exon 4 region of POU1F1 gene.

Lanes 1-6: RFLP pattern for Mandya.

Lanes 7-12: RFLP pattern for NARI-Suwarna.

Lane 13:100 bp DNA ladder.

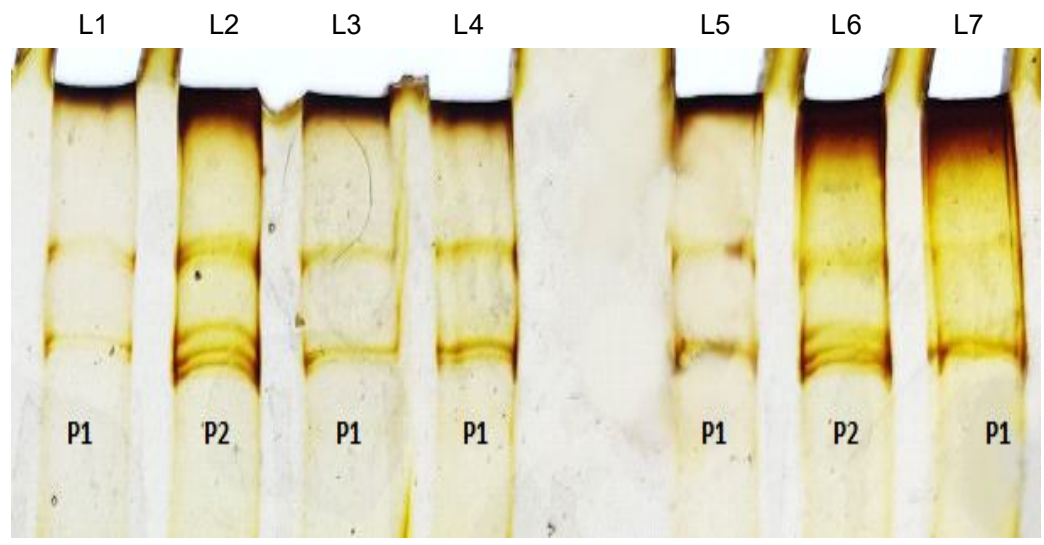

Fig 6: PAGE gel showing SSCP patterns of exon 6 region of POU1F1 gene.

Lanes 1-3: SSCP pattern for Mandya.

Lanes 4-7: SSCP pattern for NARI-Suwarna.

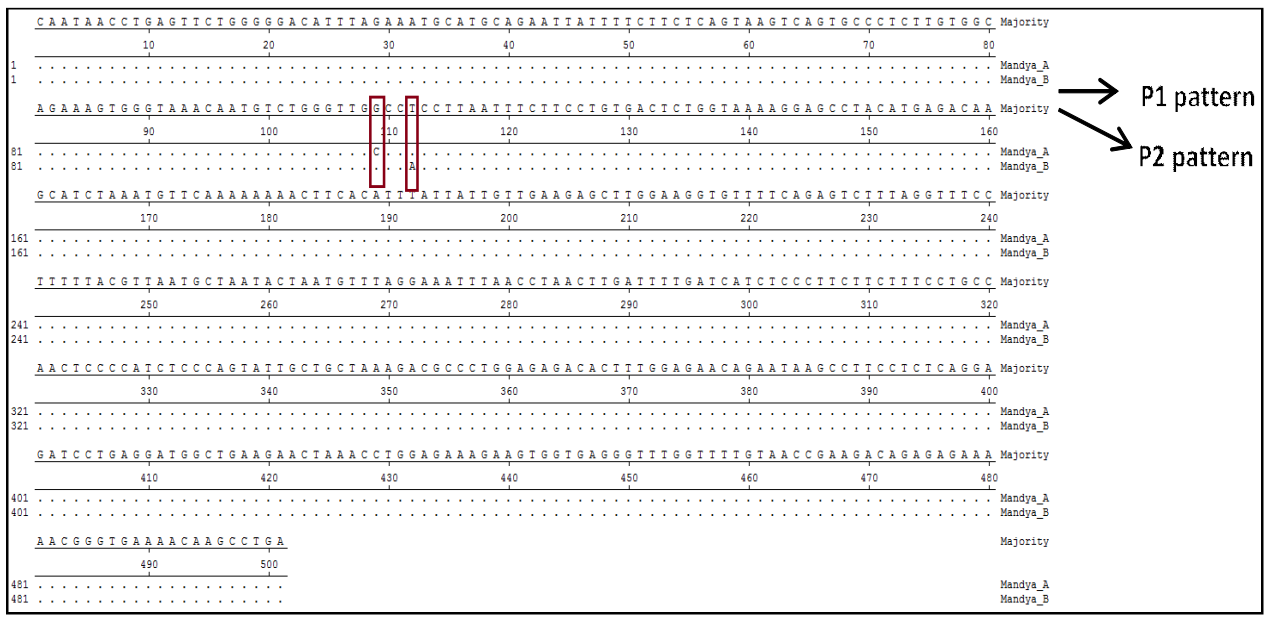

Fig 7: Alignment of $\mathrm{P} 1$ and $\mathrm{P} 2$ pattern sequences of Mandya sheep. 


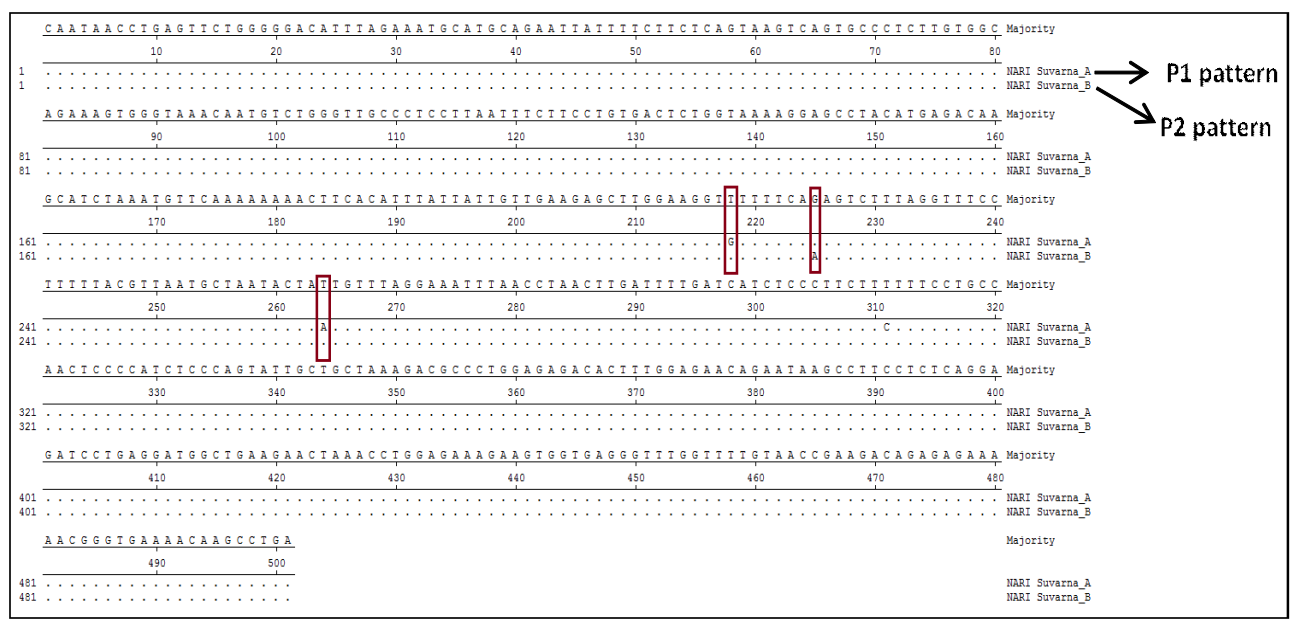

Fig 8: Alignment of $\mathrm{P} 1$ and $\mathrm{P} 2$ pattern sequences of NARI Suwarna sheep.

Mongolian sheep) of China. The three SNPs were C355T (C/T), C71G (C/G) and C330G (C/G). C allele of C355T locus was the dominant allele in all the five sheep populations.

\section{CONCLUSION}

In the present study, PCR-RFLP analysis of exon 3 and exon 4 regions of POU1F1 gene using Alul and EcoRI, respectively showed monomorphism in both Mandya and NARI-Suwarna sheep. Polymorphism was established at exon 6 region of POU1F1 gene in both Mandya and NARI-Suwarna sheep by PCR-SSCP. Mandya sheep revealed two SNPs, G to C transversion at $109 \mathrm{bp}$ position and $\mathrm{T}$ to $\mathrm{A}$ transversion at 112 bp position. NARI-Suwarna sheep revealed 3 SNPs, T to $\mathrm{G}$ transversion at $218 \mathrm{bp}, \mathrm{G}$ to $\mathrm{A}$ transition at $225 \mathrm{bp}$ and $\mathrm{T}$ to $\mathrm{A}$ transversion at $264 \mathrm{bp}$ positions.

\section{ACKNOWLEDGEMENT}

The authors are thankful to Karnataka Veterinary, Animal and Fisheries Sciences University for providing the funds to carry out the work.

\section{REFERENCES}

Acharya, R.M. (1982). Sheep and Goat Breeds of India. Food and Agriculture Organization of the United Nations. 18(21): 9-12.

Al-Khuzai, H.M. and Al-Anbari, N.N. (2018). Relationship of POU1F1 gene polymorphism with some of economical traits in Iraqi awassi ewes. Journal of Entomology and Zoology Studies. 6(2): 2082-2085.

Allan, M.F., Thallman, R.M., Cushman, R.A., Echternkamp, S.E., White, S.N., Kuehn, L.A., Casas, E. and Smith, T.P.L. (2007). Association of a single nucleotide polymorphism in SPP1 with growth traits and twinning in a cattle population selected for twinning rate. Journal of Animal Science. 85(2): 341-347.

Ansari, M., Tahmoorespur, M., Nassiri, M.R. and Javadmanesh, A. (2008). Study the PIT-1 Gene Polymorphism and Association to Average Daily Gain in Iranian Baluchi Sheep. $10^{\text {th }}$ World Congress on Animal Production, South Africa, November 23-28: 25 .
Bahrami, A., Miraei-Ashtiani, S.R., Mehrabani-Yeganeh, H., BananiRad, H. and Behzadi, S. (2014). The association between polymorphism of the $\mathrm{GH} 1$ gene and changes in protein structure and carcass traits in Mehraban sheep (Ovis aries). Animal Production Science. 55(5): 661-665.

Bai, J.Y., Wang, X., Yang, Y.B., Zhang, X.H., Pang, Y.Z. and Li, H.W. (2016). Study on the polymorphism of POU1F1 gene in sheep. Revista Brasileira de Zootecnia. 45(10): 604-607.

Bastos, E., Santos, I., Parmentier, I., Castrillo, J. L., Cravador, A., Guedes-Pinto, H. and Renaville, R. (2006). Ovis aries POU1F1 gene: Cloning, characterization and polymorphism analysis. Genetica. 126(3): 303-314.

Dinakar, H.P., Satynarayan, K., Jagadeeswary, V., Harisha, M. and Desai, A.R. (2019). Rearing pattern of bannur sheep in its home tract. International Journal of Current Microbiology and Applied Sciences. 8(6): 1416-1421.

Ekegbu, U.J., Haruna, I.L., Mahmoud, G., Zhou, H. and Hickford, J.G. (2018). Genetic polymorphisms in New Zealand sheep breeds. World Journal of Agriculture and Social Science. 1(2): 1-4. DOI: 10.33552/WJASS.2018.01.000506.

Jalil-Sarghale, A., Shahrbabak, M.M., Sharbabak, H.M., Sadeghi, M. and Mura, M.C. (2014). Association of pituitary specific transcription factor-1 (POU1F1) gene polymorphism with growth and biometric traits and blood metabolites in Iranian Zel and Lori-Bakhtiari sheep. Molecular Biology Reports. 41(9): 5787-5792.

Miller, S.A., Dykes, D.D. and Polesky, H.F. (1988). A simple salting out procedure for extracting DNA from human nucleated cells. Nucleic Acids Research. 16: 1215.

Negahdary, M., Hajihosseinlo, A. and Ajdary, M. (2013). PCR-SSCP variation of IGF1 and PIT1 genes and their association with estimated breeding values of growth traits in Makooei sheep. Genetics Research International. 1-6. DOI: 10.1155/ 2013/272346.

Nimbkar, C., Ghalsasi, P.M., Walkden-Brown, S.W. and Kahn, L.P. (2002). Breeding Program for the Genetic Improvement of Deccani Sheep of Maharashtra, India. In: Proceedings of $7^{\text {th }}$ World Congress on Genetics Applied to Livestock Production, August 19-23, Montpellier, France. CD-ROM Communication No. 25-11. 
Ozmen, O., Kul, S. and Unal, E. O. (2014). Polymorphism of sheep POU1F1 gene exon 6 and 3' UTR region and their association with milk production traits. Iranian Journal of Veterinary Research. 15(4): 331.

Sadeghi, M., Jalil-Sarghale, A. and Moradi-Shahrbabak, M. (2014). Associations of POU1F1 gene polymorphisms and protein structure changes with growth traits and blood metabolites in two Iranian sheep breeds. Journal of Genetics. 93(3): 831-835.

Sudhakar, A. (2009). Molecular polymorphism analysis of BMPR1B, IGFBP-3 and POU1F1 genes in Nilagiri and Mecheri Sheep. Ph.D., thesis, TANUVAS, Chennai.
Sumantri, C., Herdiana, D., Farajallah, A. and Rahmat, D. (2009). Polymorphism of Pituitary-Specific Transcription Factor1(Pit-1) gene at locus (Pit-1-Hinf1) and its effects on dam body weight and milk production of local sheep. Indonesian Journal of Animal and Veterinary Sciences. 14(3): 222-229.

Supakorn, C. (2009). The important candidate genes in goats- A review. Walailak Journal of Science and Technology. 6(1): 17-36. 